\title{
INSTALLED SOLAR POWER PREDICTION FOR TURKEY USING ARTIFICIAL NEURAL NETWORK AND BIDIRECTIONAL LONG SHORT-TERM MEMORY
}

\author{
Mehmet Hakan ÖZDEMIR ${ }^{1}$ \\ Murat INCE 2 \\ Batin Latif AYLAK 3 \\ Okan ORAL ${ }^{4}$ \\ Mehmet Ali TAŞ5
}

Received Date (Başvuru Tarihi):

$27 / 09 / 2020$

Accepted Date (Kabul Tarihi):

$13 / 12 / 2020$

Published Date (Yayın Tarihi):

$25 / 12 / 2020$

In the article, the first author is in the role of the Corresponding Author.

\begin{abstract}
Renewable energy sources play an essential role in sustainable development. The

Keywords:

Renewable Energy,

Solar Energy,

Prediction,

Artificial Neural Network share of renewable energy-based energy generation is rapidly increasing all over the world. Turkey has a great potential in terms of both solar and wind energy due to its geographical location. The desired level has not yet been reached in using this potential. Nevertheless, with the increase in installed power in recent years, electricity generation from solar energy has gained momentum. In this study, data on cumulative installed solar power in Turkey in the 2009-2019 period were used. Artificial Neural Network (ANN) and Bidirectional Long Short-Term Memory (BLSTM) methods were selected to predict the cumulative installed solar power for 2020 with these data. The cumulative installed power was predicted, and the results were compared and interpreted.
\end{abstract}

JEL Codes:

O20, Q42, Q47

\footnotetext{
${ }^{1}$ Dr. Öğr. Üyesi, Türk-Alman Üniversitesi, hakan.ozdemir@tau.edu.tr,

${ }^{2}$ Dr. Öğr. Üyesi, Isparta Uygulamalı Bilimler Üniversitesi, muratince@isparta.edu.tr,

${ }^{3}$ Dr. Öğr. Üyesi, Türk-Alman Üniversitesi, batin.latif@tau.edu.tr,

${ }^{4}$ Dr. Öğr. Üyesi, Akdeniz Üniversitesi, okan@akdeniz.edu.tr,

${ }^{5}$ Arş. Gör., Türk-Alman Üniversitesi, mehmetali.tas@tau.edu.tr,
}

https:// orcid.org/0000-0002-7174-9807

https://orcid.org/0000-0001-5566-5008

https://orcid.org/0000-0003-0067-1835

https://orcid.org/0000-0002-6302-4574

https:// orcid.org/0000-0003-3333-7972 


\section{TÜRKIYYE ICÇİN GÜNEŞ ENERJISII KURULU GÜCÜNÜN YAPAY SİNİR AĞI VE İKİ YÖNLÜ UZUN- KISA VADELİ BELLEK KULLANILARAK TAHMINII}

$\ddot{O Z Z}$

\author{
Anahtar Kelimeler: \\ Yenilenebilir Enerji, \\ Güneş Enerjisi, \\ Tahmin, \\ Yapay Sinir A $\breve{g} l$
}

JEL Kodlar:

O20, Q42, Q47
Sürdürülebilir bir kalkınma için yenilenebilir enerji kaynaklarn önemli bir rol oynamakta ve yenilenebilir enerji kaynakl enerji üretiminin payı tüm dünyada hızla artmaktadır. Ülkemiz, bulunduğu coğrafi konumu nedeniyle hem güneş hem de rüzgâr enerjisi açısından büyük bir potansiyele sahiptir. Bu potansiyeli kullanma konusunda henüz istenen düzeye ulaşılamamıştır. Yine de son yıllarda kurulu gücün artmasıyla birlikte güneş enerjisinden elektrik üretimi çalışmaları hız kazanmıştır. Bu çalışmada, Türkiye'nin 20092019 yılları arasındaki kümülatif güneş enerjisi kurulu gücü verileri kullanılmışıır. Bu veriler ile 2020 yılı için kümülatif kurulu gücü tahmin etmek amactyla Yapay Sinir A $\breve{g}$ (Artificial Neural Network - ANN) ve İki Yönlü Uzun-Kısa Vadeli Bellek (Bidirectional Long Short-Term Memory - BLSTM) yöntemleri kullanılmıştır. Kümülatif kurulu gü̧̈ tahmin edilmiş ve sonuçlar karşılaştırılarak yorumlanmıştır.

\section{INTRODUCTION}

The energy needs of countries are increasing day by day. As a result of increasing consumption, fossil energy resources in the world are rapidly running out. Nevertheless, fossil energy resources still have a considerable share in primary energy consumption across the world. Primary energy consumption by sources in 2018 and 2019 is shown for the entire world in Figure 1 and Figure 2. As can be seen from the Figures, the primary energy consumption originating from fossil energy resources is over $80 \%$ in both years. Moreover, Turkey's primary energy consumption by sources in 2018 and 2019 is shown in Table 1. Hydroelectric energy data are not given under renewable energy in the reference. 


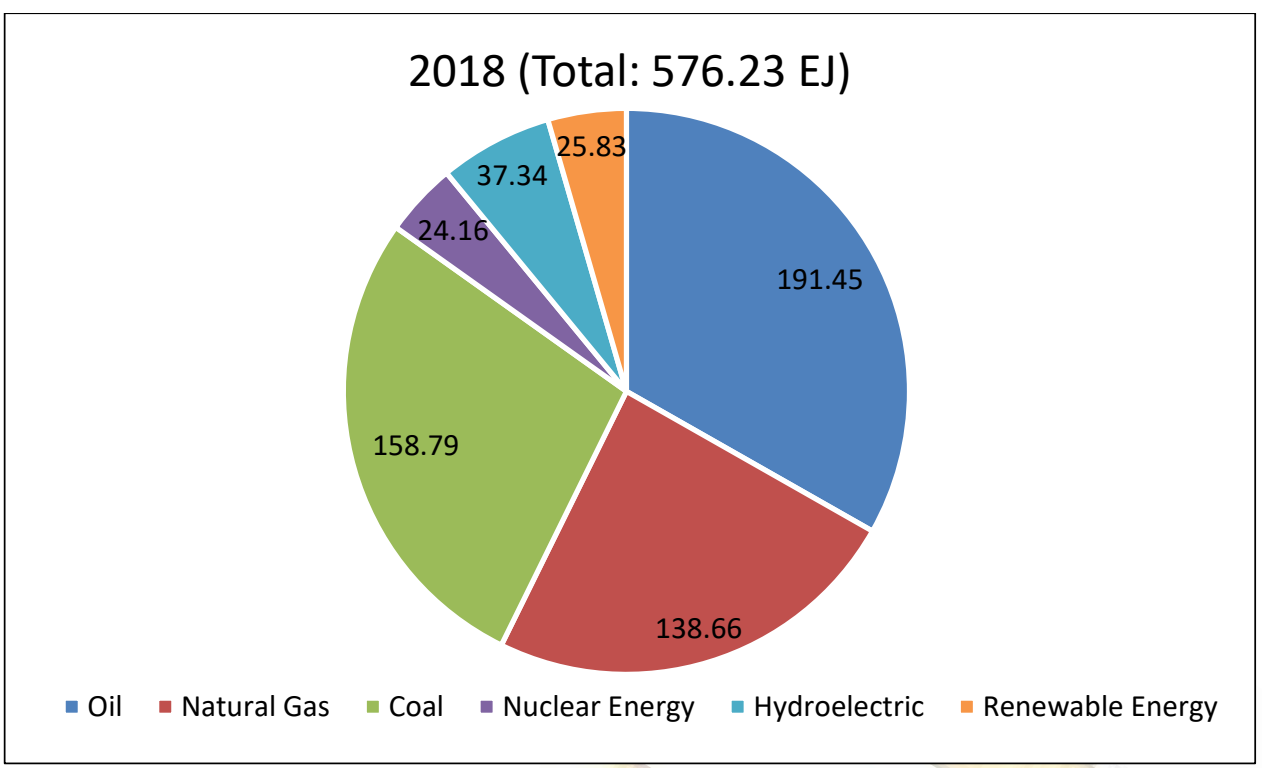

Figure 1. Primary energy consumption in EJ by sources in 2018 (BP, 2020a:9)

Because of the rapid consumption of these resources, renewable energy sources are essential. Besides, as it is known, fossil energy resources cause global warming, leading to various natural disasters. It is crucial to turn to clean, reliable and sustainable renewable energy sources instead of fossil energy resources, which are known to cause significant damage to the environment (Kılıç, 2015:29).

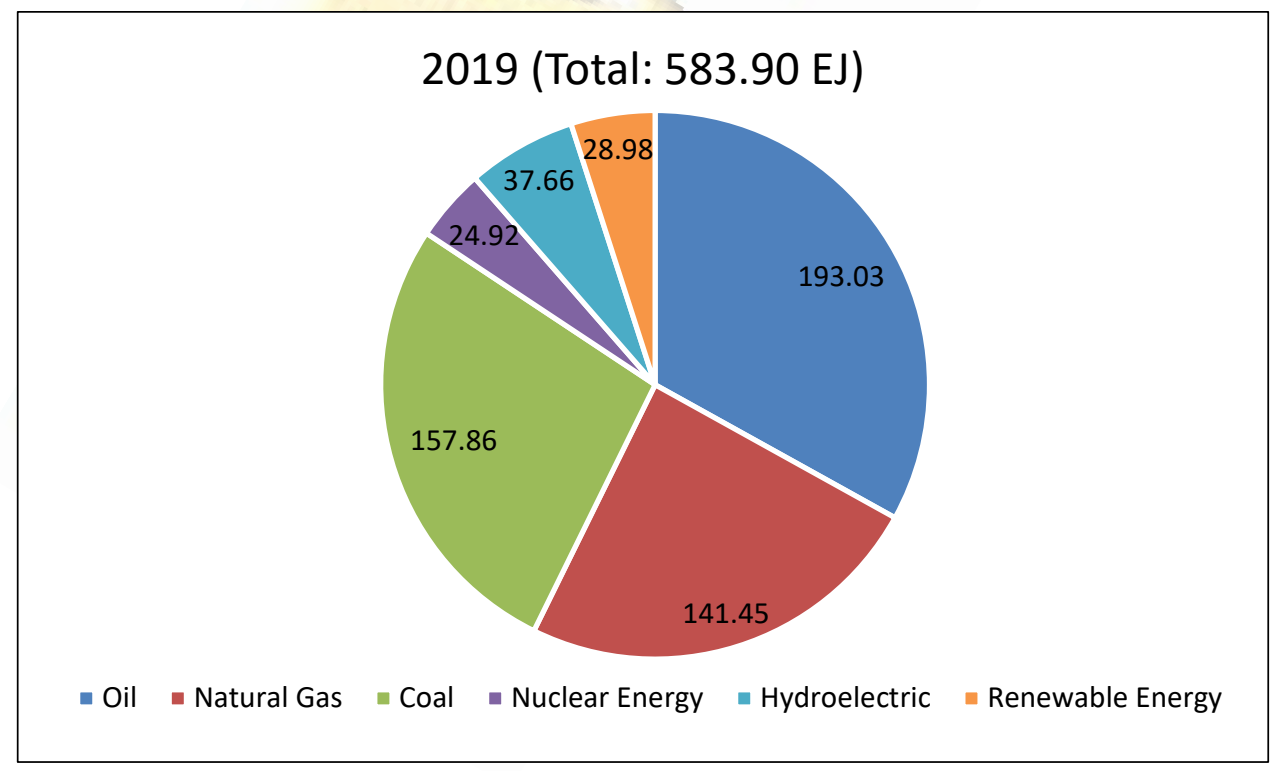

Figure 2. Primary energy consumption in EJ by sources in 2019 (BP, 2020a:9) 
Table 1. Turkey's primary energy consumption in EJ by sources in 2018 and 2019 (BP, 2020a:9)

\begin{tabular}{|c|c|c|c|c|c|c|c|}
\hline Year & Oil & Natural Gas & Coal & $\begin{array}{c}\text { Nuclear } \\
\text { Energy }\end{array}$ & Hydroelectric & $\begin{array}{c}\text { Renewable } \\
\text { Energy }\end{array}$ & Total \\
\hline $\mathbf{2 0 1 8}$ & 2.00 & 1.70 & 1.71 & - & 0.54 & 0.34 & 6.29 \\
\hline $\mathbf{2 0 1 9}$ & 2.03 & 1.56 & 1.70 & - & 0.79 & 0.41 & 6.49 \\
\hline
\end{tabular}

In addition to the damage caused by fossil energy resources to the environment, our country is heavily dependent on foreign resources in energy supply. Since the 1980s, imported energy resources have been used to meet energy needs. Moreover, high-cost investments in terms of fossil-based imports have come besides. Thus, dependency on foreign resources in energy supply reached a very high level of $72.4 \%$ in 2018. Consequently, the cost to our country was $\$ 43$ billion in 2018 and $\$ 41.6$ billion in 2019 (MMO, 2020). It is clear that this situation creates a vast burden on our country's economy and leads to an increase in the current account deficit.

On the other hand, renewable energy costs are decreasing day by day, thanks to technological developments (KPMG, 2019:3). Furthermore, due to its geographical location, Turkey is highly advantageous in solar and wind energy production (Kayıkc1 and Kılıç, 2019:213), and increasing the use of these resources will decrease external dependency. (Ceylan and Başer, 2014:57).

Turkey has a high solar energy potential thanks to its location in the so-called sumbelt (Altuntop and Erdemir, 2013:70). Distribution of Turkey's total solar energy potential by regions and months is shown in Table 2 and Table 3. Table 2 shows the total solar energy potential in $\mathrm{kWh} / \mathrm{m}^{2}$ and sunshine duration hours per year for each region. Table 3 shows the total solar energy potential in $\mathrm{kcal} / \mathrm{cm}^{2}$ and $\mathrm{kWh} / \mathrm{m}^{2}$ and sunshine duration hours per month for Turkey. 
Table 2. Distribution of Turkey's Solar Energy Potential by Regions (MMO, 2014:167)

\begin{tabular}{|c|c|c|}
\hline Region & $\begin{array}{c}\text { Total Solar Energy } \\
\text { (kWh/m²-year) }\end{array}$ & $\begin{array}{c}\text { Sunshine Duration } \\
\text { (hour/year) }\end{array}$ \\
\hline Southeastern Anatolia & 1460 & 2993 \\
\hline Mediterranean & 1390 & 2956 \\
\hline Eastern Anatolia & 1365 & 2664 \\
\hline Central Anatolia & 1314 & 2628 \\
\hline Aegean & 1304 & 2738 \\
\hline Marmara & 1168 & 2409 \\
\hline Black Sea & & 1971 \\
\hline
\end{tabular}


Table 3. Distribution of Turkey's Total Solar Energy Potential by Months (MMO, 2014:166)

\begin{tabular}{|c|c|c|c|}
\hline Months & $\begin{array}{l}\text { Monthly Total } \\
\text { kcal/cm²-month }\end{array}$ & $\begin{array}{l}\text { Solar Energy } \\
\text { kWh/m²-month }\end{array}$ & $\begin{array}{c}\text { Sunshine Duration } \\
\text { (hour/month) }\end{array}$ \\
\hline January & 4.45 & 51.75 & 103.0 \\
\hline February & 5.44 & 63.27 & 115.0 \\
\hline March & 8.31 & 96.65 & 165.0 \\
\hline April & 10.51 & 12 & 197.0 \\
\hline May & 13.23 & 153.86 & 273.0 \\
\hline June & 14.51 & 168.75 & 325.0 \\
\hline July & 15.08 & 175.38 & 365.0 \\
\hline August & 3.6 & 158.40 & 343.0 \\
\hline September & 10.60 & 123.28 & 280.0 \\
\hline October & 7.73 & 89.90 & 214.0 \\
\hline November & & 60.82 & 157.0 \\
\hline December & 4.03 & 46.87 & 103.0 \\
\hline Total & 112.74 & 1311.0 & 2640.0 \\
\hline Average & $308.0 \mathrm{kcal} / \mathrm{cm}^{2}$-day & $3.6 \mathrm{kWh} / \mathrm{m}^{2}$-day & 7.2 hour/day \\
\hline
\end{tabular}


However, not using this potential effectively causes solar energy not to be counted as a solution alternative to the problems above. Efforts should be made to use solar energy effectively and sustainably in our country (K1lıç, 2015:30).

Generally, photovoltaic (PV) solar power systems and concentrated solar power (CSP) systems are used in electricity generation from solar energy (ETKB, 2020).

Turkey has 6901 solar power plants by the end of 2019, and the cumulative installed solar power is 5996 MW (TEİAŞ, 2019; BP, 2020b:A2). Turkey's cumulative installed solar power by years is shown in Table 4.

Table 4. Turkey's cumulative installed solar power by years (BP, 2020b:A2)

\begin{tabular}{|c|c|c|c|c|c|c|c|c|c|c|c|}
\hline Years & $\mathbf{2 0 0 9}$ & $\mathbf{2 0 1 0}$ & $\mathbf{2 0 1 1}$ & $\mathbf{2 0 1 2}$ & $\mathbf{2 0 1 3}$ & $\mathbf{2 0 1 4}$ & $\mathbf{2 0 1 5}$ & $\mathbf{2 0 1 6}$ & $\mathbf{2 0 1 7}$ & $\mathbf{2 0 1 8}$ & $\mathbf{2 0 1 9}$ \\
\hline $\begin{array}{c}\text { Cumulative } \\
\text { installed } \\
\text { solar } \\
\text { power (MW) }\end{array}$ & 5 & 6 & 7 & 12 & 19 & 41 & 250 & 834 & 3422 & 5064 & 5996 \\
\hline
\end{tabular}

Table 5 shows the distribution of Turkey's electricity generation in terawatthours by energy sources in 2018 and 2019.

Table 5. Electricity generation in Turkey by energy sources (BP:2020a:61)

\begin{tabular}{|c|c|c|c|c|c|c|c|c|c|c|}
\hline \multirow[t]{2}{*}{ Year } & \multirow[t]{2}{*}{ Oil } & \multirow[t]{2}{*}{ Natural Gas } & \multirow[t]{2}{*}{ Coal } & \multirow[t]{2}{*}{ Nuclear Energy } & \multirow[t]{2}{*}{ Hydroelectric } & \multicolumn{3}{|c|}{$\begin{array}{c}\text { Renewable } \\
\text { Energy }\end{array}$} & \multirow[t]{2}{*}{ Other } & \multirow[t]{2}{*}{ Total } \\
\hline & & & & & & Wind & Solar & Other & & \\
\hline 2018 & 0.3 & 92.5 & 113.2 & - & 59.9 & 19.9 & 7.8 & 10.1 & 1.0 & 304.8 \\
\hline 2019 & 0.2 & 58.1 & 114.6 & - & 89.2 & 21.7 & 10.9 & 12.7 & 1.1 & 308.5 \\
\hline
\end{tabular}


Both Table 4 and Table 5 show that there are developments in the field of solar energy. However, these developments are insufficient. Our country, which has a high potential for solar energy, will reduce its external dependency and remove many uncertainties in the future due to fossil energy resources by increasing installed solar power and using our solar potential better.

Prediction plays a vital role in the field of energy. Various studies in the literature have made predictions using ANN methods. Elizondo, Hoogenboom and McClendon (1994) developed an ANN model to predict daily solar radiation. Mohandes, Rehman and Halawani (1998) estimated global solar radiation using ANNs. Li, Wunsch, O'Hair and Giesselmann (2001) estimated wind turbine energy production using ANNs. Reddy and Ranjan (2003) estimated the average daily and hourly values of global solar radiation using ANNs and compared this with other correlation models. Sözen (2004) mapped Turkey's solar potential using ANNs. Sözen, Arcaklioglu, Ozalp and Caglar (2005) forecasted the solar potential of Turkey with ANNs. Zhou, Wu and Yan (2005) estimated solar radiation using ANNs. Bilgili, Sahin and Yasar (2007) used ANNs to predict wind speed at the target station with reference station data. Ata (2008) analyzed the energy yield of an autonomous wind turbine at different heights using ANNs. Rehman and Mohandes (2008) estimated global solar radiation with ANNs using air temperature and relative humidity. Lam, Wan and Yang (2008) modelled solar radiation with ANNs for different climates of China. Bosch, Lopez and Batlles (2008) estimated daily solar radiation in a mountainous region using ANNs. Mabel and Fernandez (2008) predicted wind power generation. Senkal and Kaleli (2009) estimated solar radiation in Turkey using ANNs and satellite data. Fadare (2009) modelled the solar energy potential in Nigeria using an ANN model. Taşcıkaraoğlu and Uzunoğlu (2011) predicted wind speed by using the wavelet transform (WT) and ANNs. Khatib, Mohamed, Sopian and Mahmoud (2012) predicted solar power generation for Malaysia using ANNs. Mellit, Sağlam and Kalogirou (2013) estimated the energy to be produced by a PV module with an ANN-based model. Kıliç and Arabacı (2015) predicted future wind speed values for Burdur province by using ANN method. Kaya, Caner and Oğuz (2016) determined the wind potential of Kastamonu province by modelling six different wind turbines and using ANNs and 
adaptive neuro-fuzzy inference systems. Dumitru, Gligor and Enachescu (2016) forecasted photovoltaic energy production using ANNs. Li, Rahman, Vega and Dong (2016) developed a hierarchical approach for forecasting photovoltaic energy production using machine learning methods. Şahan and Yüksel (2016) predicted solar energy using ANNs with meteorological data from the Mediterranean region. Şenol and Musayev (2017) predicted electricity generation from wind energy with ANNs. Filik and Filik (2017) developed a new hybrid approach based on autoregressive and ANNs for prediction of short-term wind speed. Özsoy and Aydogan (2017) used ANNs for predicting installed wind power in Turkey. Şenol (2017) predicted wind energy and wind energy potential using ANNs in his master's thesis. Dumitru and Gligor (2017) forecasted the daily average energy production for wind energy with ANNs. Karasu, Altan, Sarac and Hacioglu (2017) predicted solar radiation with machine learning methods. Çevik, Çakmak and Altaş (2017) made a forecast of hourly solar radiation for Trabzon province a day ahead with the help of ANNs. Köse, Atila, Güneşer and Recebli (2018) developed a new analytical method for estimating hourly and daily wind speed and compared the results with estimates obtained with ANNs. Kırbaş (2018) made a short-term multi-step wind speed prediction using statistical methods and ANNs. Cantürk (2018) predicted electricity from a wind farm with ANNs in his master's thesis. Altınsoy and Bal (2019) used ANNs in long-term wind speed predictions and conducted a performance review. Huang and Kuo (2018) forecasted short-term wind speed with ANNs. Uğuz, Oral and Çağlayan (2019) predicted the energy to be obtained from PV power plants using machine learning methods. Gabralı and Aslan (2020) estimated short and medium-term solar radiation in Istanbul Büyükçekmece District with ANNs.

In this study, cumulative installed solar power was predicted for Turkey with ANN and BLSTM. As far as we reviewed, there is no such study using these two methods in order to predict the cumulative installed solar power for Turkey. It was aimed to assist in energy production planning for the future and guide in the correct direction of energy investments to be made. 


\section{ARTIFICIAL NEURAL NETWORK}

Various prediction methods are used in the literature. In this study, it is aimed to predict the cumulative installed solar power by using ANN and BLSTM. ANNs are an artificial intelligence and machine learning method inspired by biological nerve cells (Esfe, Saedodin, Sina, Afrand and Rostami, 2015:51). ANNs generally consist of an input layer, one or multiple hidden layers, and an output layer, neurons in these layers and weights. Figure 3 shows a network with 24 neurons. This method is used for prediction and classification from existing data. For this purpose, the system is trained with real data and then it is expected to produce outputs suitable for test data. ANN is used for classification and prediction purposes in many areas such as skin cancer level determination (Esteva, Kuprel, Novoa, Ko, Swetter, Blau and Thrun, 2017), detection of automobile engine faults (Ahmed, El Sayed, Gadsden, Tjong and Habibi, 2014), drug classification (Byvatov, Fechner, Sadowski and Schneider, 2003), electric load estimation (Park, El-Sharkawi, Marks, Atlas and Damborg, 1991), stock market forecast (Ticknor, 2013), wind speed estimation (Khosravi, Koury, Machado and Pabon, 2018) and electricity energy demand forecasting (Özden and Öztürk, 2018) because of its adaptability, non-linearity and arbitrary function mapping ability (Garg, Sharma, Parmar, Soni, Singh and Maji, 2016).

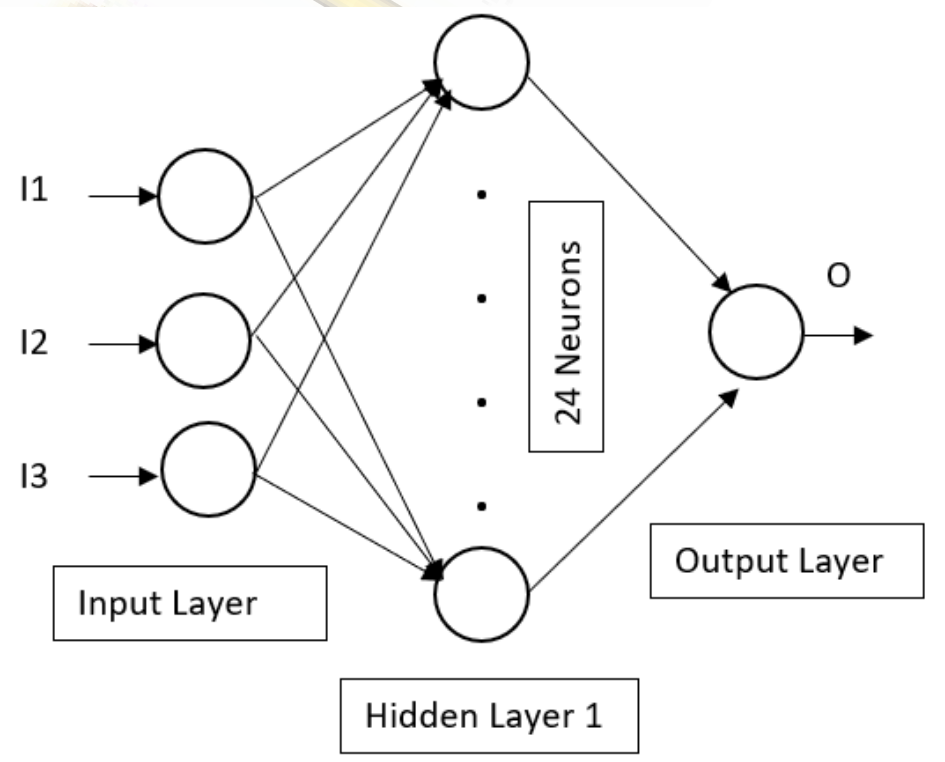

Figure 3. Network in structure 3-24-1 
Another popular algorithm inspired by ANNs is deep learning (networks) algorithms. These algorithms are used in many areas such as image processing, classification and natural language processing (Deng and $\mathrm{Yu}, 2014: 202)$. These methods, which we can call deep learning networks, are different from classical ANNs in various ways, such as layer numbers (LeCun, Bengio and Hinton, 2015:436). Convolutional Neural Network (CNN) and Recurrent Neural Network (RNN) are the most well-known deep learning algorithms. RNNs can handle input sequences of sequential length and time series problems, but gradient can descend or ascend in the training process (Salamon and Bello, 2017, Bengio, Simard and Frasconi, 1994). This can cause gradient loss issues in training and cause learning problems not to find the correct relationships in the sequences of the RNN model. This is now LSTM which is a particular version of the regular RNN. Employees such as LSTM speech recognition (Hughes and Mierle, 2013), signal works (Yildirim, 2018), text classification (Zhou, Qi, Zheng, Xu, Bao and Xu, 2016), video identification (Bin, Yang, Shen, Xie, Shen and Li, 2018) are used. Normal (One Way) LSTMs can fail in sequential operations such as time series since they do one operation (Graves and Schmidhuber, 2005). For this reason, BLSTMs are a connection and run two LSTMs in the input sequence instead of one LSTM in problems where the input sequence is all time steps (Figure 4). The first LSTM can be made over the input sequence (from past to future) and the second LSTM operates in the opposite direction (from the future to the past) on the copy of the input sequence (Kiperwasser and Goldberg, 2016:316). Thus, it can enable the system to learn the problem faster and more completely.

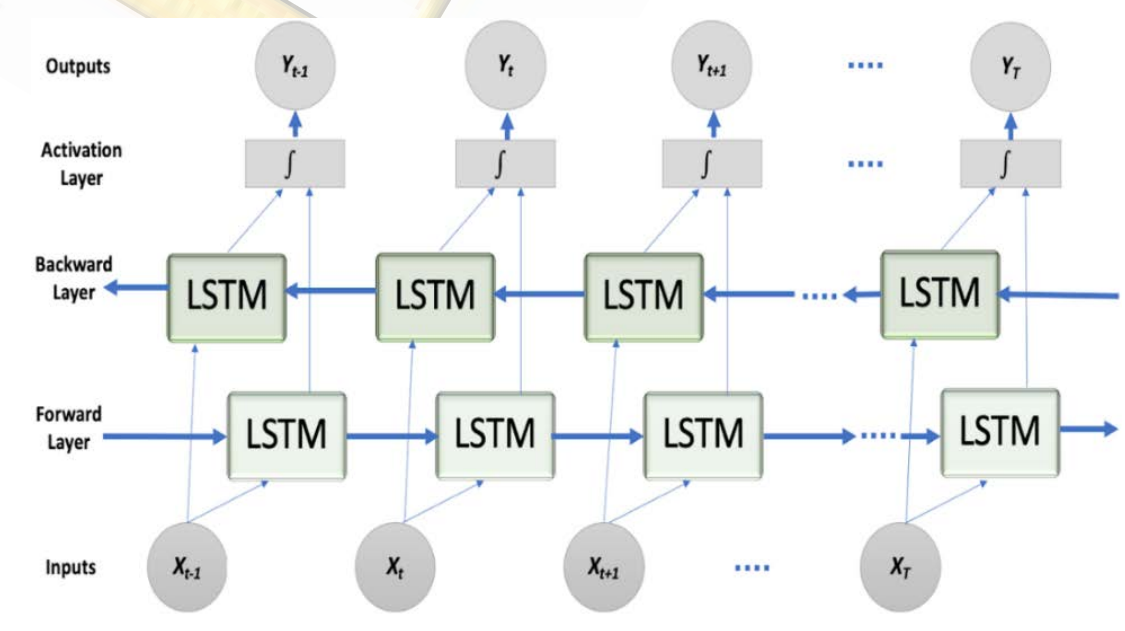

Figure 4. BLSTM structure 


\section{IMPLEMENTATION}

In this study, Turkey's data on cumulative installed solar power given in Table 4 for the period 2009-2019 were used. The data were collected from an online database. Therefore, an Ethics Committee Permission was not required in this study. Since the limited and one-dimensional data available are a time series, it is necessary to make use of historical data for prediction. In order to get good results, the data were transformed into a series with three elements. ANN and BLSTM methods were used on these series, which gives good results in prediction processes. In both methods, the cumulative installed solar power values in megawatts of consecutive years were used as three inputs (I1, I2, I3), and the cumulative installed solar power value of the year after these consecutive years as the only output (O) (Table 6). The values of I1, I2, I3, and $\mathrm{O}$ in the first row are the cumulative installed solar power data for the years 2009, 2010, 2011, and 2012 in Table 4, respectively. The second input value in the first row is used as the first input value in the second row. The third input value in the first row is used as the second input value in the second row. The output value in the first row is used as the third input value in the second row. This shifting is continued for the remaining six rows. In other words, the values in the first row are from 2009, 2010, 2011, and 2012, respectively, while those in the second row are 2010, 2011, 2012, and 2013. This process is continued until 2019. The aim here is to produce data series to be applied in the method. 
Table 6. Three-element data set of installed solar power values for the period 20092019

\begin{tabular}{|l|l|l|l|}
\hline I1 & I2 & I3 & O \\
\hline 5 & 6 & 7 & 12 \\
\hline 6 & 7 & 12 & 19 \\
\hline 7 & 12 & 19 & 41 \\
\hline 12 & 19 & 41 & 250 \\
\hline 19 & 41 & 250 & 834 \\
\hline 41 & 250 & 834 & 3422 \\
\hline 250 & 834 & 3422 & 5064 \\
\hline
\end{tabular}

The ANN method includes three inputs, one output and one hidden layer (324-1) with 24 neurons. It was carried out with 200 epochs during ANN training, and from the data for the years 2016, 2017 and 2018, a value of 5995.989 was estimated for the actual value 5996. A relative error has been found $-0.0002 \%$ after comparing both values (Table 7).

BLSTM method was trained with 50 epochs, and Adam optimizer was used. Instead of the classical stochastic gradient reduction method, Adam is a more efficient, adaptive optimization algorithm, i.e. it updates the learning rate for each parameter (Kingma and Ba, 2014:1, Ruder, 2016:7).

By this method, a value of 6146.651 was estimated for the actual value 5996 for 2019. A relative error has been found $2.5125 \%$ after comparing both values (Table 7 ). 
Table 7. Prediction for 2019 from the data for the period 2016-2018

\begin{tabular}{|l|l|l|l|l|}
\hline Methodology & 2016 & 2017 & 2018 & 2019 \\
\hline Actual values in MW & 834 & 3422 & 5064 & 5996 \\
\hline ANN Prediction in MW (Relative Error -0.0002\%) & 5995.989 \\
\hline Bidirectional LSTM Prediction in MW (Relative Error 2.5125\%) & 6146.651 \\
\hline
\end{tabular}

Moreover, the ANN method is implemented on the data for the period 20162018 in order to predict the cumulative installed solar power value for 2019 with different network structures. As shown in Table 8, the best prediction value is obtained by the 3-24-1 network structure.

Table 8. Prediction for 2019 with different network structures

\begin{tabular}{|l|l|l|}
\hline Network Structure & Prediction in MW & Relative Error \% \\
\hline $3-5-3-1$ & 6009.53 & 0.2257 \\
\hline $3-5-5-1$ & 5627.861 & -6.1397 \\
\hline $3-3-5-1$ & 5876.123 & -1.9993 \\
\hline $3-10-5-1$ & 5805.749 & -3.1730 \\
\hline $3-5-10-1$ & 5601.440 & -6.5804 \\
\hline $3-5-1$ & 5674.155 & -5.3677 \\
\hline $3-8-1$ & 5992.897 & -0.0518 \\
\hline $3-11-1$ & 5995.281 & -0.0120 \\
\hline $3-14-1$ & 5995.632 & -0.0061 \\
\hline $3-17-1$ & 5995.931 & -0.0012 \\
\hline $3-20-1$ & 5995.930 & -0.0012 \\
\hline $3-24-1$ & 5995.989 & -0.0002 \\
\hline
\end{tabular}


ANN and BLSTM methods were used to estimate the value for 2020 from the data for 2017, 2018, and 2019 with the same training and optimization parameters. The cumulative installed solar power value was predicted as 6499.992 for the year 2020 by the ANN method and as 6617.015 by the BLSTM method (Table 9). Although the actual value for 2020 is unknown, the cumulative installed solar power is $6294.7 \mathrm{MW}$ by the end of August 2020 (TEİAŞ, 2020).

Table 9. Prediction for 2020 from the data for the period 2017-2019

\begin{tabular}{|c|c|c|c|c|}
\hline Year & 2017 & 2018 & 2019 & 2020 \\
\hline Actual Value & 3422 & 5064 & 5996 & - \\
\hline \multicolumn{2}{|c|}{ ANN Prediction } & 6499.992 \\
\hline \multicolumn{2}{|c|}{ BLSTM Prediction } & 6617.015 \\
\hline
\end{tabular}

Furthermore, the ANN method is implemented on the data for the period 20172019 in order to predict the cumulative installed solar power value for 2020 with different network structures. The results are given in Table 10. 
Table 10. Prediction for 2020 with different network structures

\begin{tabular}{|c|c|}
\hline Network Structure & Prediction in MW \\
\hline $3-5-5-1$ & 6341.412 \\
\hline $3-3-5-1$ & 6442.569 \\
\hline $3-10-5-1$ & 6367.772 \\
\hline $3-5-10-1$ & 6356.365 \\
\hline $3-5-1$ & 6230.179 \\
\hline $3-8-1$ & 6375.942 \\
\hline $3-11-1$ & 6499.175 \\
\hline 3-14-1 & 6499.123 \\
\hline $3-17-1$ & 6499.834 \\
\hline $3-20-1$ & 6499.925 \\
\hline $3-24-1$ & 6499.992 \\
\hline
\end{tabular}

In order to compare the results of the ANN and BLSTM methods, other prediction methods such as Support Vector Regression (SVR), Decision Tree Regression (DTR) and Random Forest Regression (RFR) are implemented on the same data with optimized parameters in order to predict the cumulative installed solar power value for 2020 (Table 11). 
Table 11. Comparison of the results obtained from ANN and BLSTM methods with the results of other prediction methods

\begin{tabular}{|c|c|c|}
\hline Prediction Method & $\begin{array}{c}\text { Prediction for 2019 } \\
\text { (Actual value is 5996 MW) }\end{array}$ & $\begin{array}{c}\text { Prediction for 2020 } \\
\text { (Actual value is unknown) }\end{array}$ \\
\hline ANN & 5995.989 & 6499.992 \\
\hline BLSTM & 6146.651 & 6617.015 \\
\hline SVR & 2945.31 & 3429.96 \\
\hline DTR & 5064 & 5996 \\
\hline RFR & 4336.26 & 5490.98 \\
\hline
\end{tabular}

As shown in Table 11, the ANN method yielded the best prediction result for 2019 when compared with other prediction methods. Since the value for 2020 is unknown, it can not be determined which method gives the best result.

\section{CONCLUSION}

In this study, the cumulative installed solar power was predicted for 2020 by using ANN and BLSTM. The results show that the ANN method yields a better result than the BLSTM method for 2019. The predicted value for 2020 may not be reached due to the pandemic, as the pandemic has negatively impacted energy investments in every field. Investments in solar energy in Turkey are expected to increase with the decline in the impact of the pandemic. Turkey has great potential in solar energy. Considering this potential, it should be aimed to produce their own energy in uncultivated land, on house and company roofs that are exposed to the sun.

In future research, by considering the solar power capacity and the capacity of other renewable energy sources in Turkey, their contributions to the national economy can be analyzed financially by years, and the contribution of solar energy to the economy can be estimated over the years with the machine learning methods. 


\section{REFERENCES}

Ahmed, R., El Sayed, M., Gadsden, S. A., Tjong, J., and Habibi, S. (2014). Automotive internalcombustion-engine fault detection and classification using artificial neural network techniques. IEEE Transactions on vehicular technology, 64(1), 21-33.

Altınsoy, M., and Bal, G. (2019). Uzun dönem rüzgar hızı tahmininde yapay sinir ağlarının kullanımı ve performans incelemesi. Mesleki Bilimler Dergisi (MBD), 8(1), 21-28.

Altuntop, N., and Erdemir, D. (2013). Dünyada ve Türkiye'de Güneş Enerjisi ile İlgili Gelişmeler. Mühendis ve Makine, 54(639), 69-77.

Ata, R. (2008). Otonom Bir Rüzgâr Türbininin Farklı Yüksekliklerdeki Enerji Eldesini YSA ile Analizi. Journal of the Faculty of Engineering \& Architecture of Gazi University, 23(3), 523-529.

Bengio, Y., Simard, P., and Frasconi, P. (1994). Learning long-term dependencies with gradient descent is difficult. IEEE transactions on neural networks, 5(2), 157-166.

Bilgili, M., Sahin, B., and Yasar, A. (2007). Application of artificial neural networks for the wind speed prediction of target station using reference stations data. Renewable Energy, 32, 2350-2360.

Bin, Y., Yang, Y., Shen, F., Xie, N., Shen, H. T., and Li, X. (2018). Describing video with attention-based bidirectional LSTM. IEEE transactions on cybernetics, 49(7), 2631-2641.

Bosch, J. L., Lopez, G., and Batlles, F. J. (2008). Daily solar irradiation estimation over a mountainous area using artificial neural network. Renewable Energy, 33, 1622-1628.

BP British Petrol (2020a). Full Report - BP Statistical Review of World Energy 2020, https://www.bp.com/content/dam/bp/business-sites/en/global/corporate/pdfs/energyeconomics/statistical-review/bp-stats-review-2020-full-report.pdf (01.09.2020).

BP British Petrol (2020b). Renewable Energy - BP Statistical Review of World Energy 2020, https://www.bp.com/content/dam/bp/business-sites/en/global/corporate/pdfs/energyeconomics/statistical-review/bp-stats-review-2020-renewable-energy.pdf (01.09.2020).

Byvatov, E., Fechner, U., Sadowski, J., and Schneider, G. (2003). Comparison of support vector machine and artificial neural network systems for drug/nondrug classification. Journal of chemical information and computer sciences, 43(6), 1882-1889.

Cantürk, S. (2018). Bir rüzgar çiftliğinden yapay sinir ağlarıyla kısa süreli elektrik üretim tahmini. Hacettepe University Graduate School of Science and Engineering, Master's Thesis, Ankara.

Ceylan, R., and Başer, S. (2014). Türkiye'de Petrol Tüketimi İle Reel GSYİH Arasındaki Uzun Dönem İlişkinin Johansen Eş-Bütünleşme Yöntemi İle Analiz Edilmesi. Business \& Economics Research Journal, 5(2), 47-60. 
Çevik, S., Çakmak, R., and Altaş, İ. H. (2017). A day ahead hourly solar radiation forecasting by artificial neural networks: A case study for Trabzon province. 2017 international artificial intelligence and data processing symposium (IDAP), 16-17 September, Malatya, Turkey, 1-6.

Deng, L., and Yu, D. (2014). Deep learning: methods and applications. Foundations and trends in signal processing, 7(3-4), 197-387.

Dumitru, C. D., Gligor, A., and Enachescu, C. (2016). Solar photovoltaic energy production forecast using neural networks. Procedia Technology, 22, 808-815.

Dumitru, C. D., and Gligor, A. (2017). Daily average wind energy forecasting using artificial neural networks. Procedia Engineering, 181, 829-836.

Elizondo, D., Hoogenboom, G., and McClendon, R. W. (1994). Development of a neural network model to predict daily solar radiation. Agricultural and Forest Meteorology, 71(1-2), 115-132.

Esfe, M. H., Saedodin, S., Sina, N., Afrand, M., and Rostami, S. (2015). Designing an artificial neural network to predict thermal conductivity and dynamic viscosity of ferromagnetic nanofluid. International Communications in Heat and Mass Transfer, 68, 50-57.

Esteva, A., Kuprel, B., Novoa, R. A., Ko, J., Swetter, S. M., Blau, H. M., and Thrun, S. (2017). Dermatologist-level classification of skin cancer with deep neural networks. Nature, 542(7639), 115-118. ETKB (2020). Enerji ve Tabii Kaynaklar Bakanlığı Bilgi Merkezi “Güneş”. https://enerji.gov.tr/bilgimerkezi-enerji-gunes (02.09.2020).

Fadare, D. A. (2009). Modeling of solar energy potential in Nigeria using an artificial neural network model. Applied Energy, 86, 1410-1422.

Filik, Ü. B., and Filik, T. (2017). Kısa-Dönem Rüzgâr Hızının Tahmininde Otoregresif ve Yapay Sinir Ağları Tabanlı Yeni Bir Hibrit Yaklaşım. Karaelmas Science and Engineering Journal, 7(2), 419-427.

Gabralı, D., and Aslan, Z. (2020). Güneş Enerjisi Potansiyelinin Çoklu Lineer Regresyon ve Yapay Sinir Ağları ile Modellenmesi. AURUM Mühendislik Sistemleri ve Mimarlık Dergisi, 4(1), 23-36.

Garg, N., Sharma, M. K., Parmar, K. S., Soni, K., Singh, R. K., and Maji, S. (2016). Comparison of ARIMA and ANN approaches in time-series predictions of traffic noise. Noise Control Engineering Journal, 64(4), 522-531.

Graves, A., and Schmidhuber, J. (2005). Framewise phoneme classification with bidirectional LSTM and other neural network architectures. Neural networks, 18(5-6), 602-610.

Huang, C. J., and Kuo, P. H. (2018). A short-term wind speed forecasting model by using artificial neural networks with stochastic optimization for renewable energy systems. Energies, 11(10), 2777. 
Hughes, T., and Mierle, K. (2013). Recurrent neural networks for voice activity detection. 2013 IEEE International Conference on Acoustics, Speech and Signal Processing, 26-31 May, Vancouver, Canada, 7378-7382.

Karasu, S., Altan, A., Sarac, Z., and Hacioglu, R. (2017). Prediction of solar radiation based on machine learning methods. The journal of cognitive systems, 2(1), 16-20.

Kaya, Ü., Caner, M., and Oğuz, Y. (2016). Rüzgar Türbin Modelleri Kullanarak Kastamonu İli Rüzgar İle Elektrik Üretim Potansiyeli Tahmini. Technological Applied Sciences, 11(3), 65-74.

Kayıkcı, B., and Kılıç, F. Ç. (2019). Aydın İlinde Bir Konut için Hibrit Yenilenebilir Enerji Sistemi Fizibilitesi. 2019 International Congress of Energy Economy and Security, 06-07 April, İstanbul, Turkey, 213-225.

Khatib, T., Mohamed, A., Sopian, K., and Mahmoud, M. (2012). Solar energy prediction for Malaysia using artificial neural networks. International Journal of Photoenergy, 2012, 1-16.

Khosravi, A., Koury, R. N. N., Machado, L., and Pabon, J. J. G. (2018). Prediction of wind speed and wind direction using artificial neural network, support vector regression and adaptive neuro-fuzzy inference system. Sustainable Energy Technologies and Assessments, 25, 146-160.

Kılıç, B., and Arabacı, E. (2015) Burdur İli Gelecekteki Rüzgar Hızı Değerlerini Yapay Sinir Ağları Metodu ile Tahmini. Dumlupınar Üniversitesi Fen Bilimleri Enstitüsü Dergisi, (2015 Special Issue), 4550.

Kılıç, F. Ç. (2015). Güneş enerjisi, Türkiye'deki son durumu ve üretim teknolojileri. Mühendis ve Makina, 56(671), 28-40.

Kırbaş, İ. (2018). İstatistiksel metotlar ve yapay sinir ağları kullanarak kısa dönem çok adımlı rüzgâr hızı tahmini. Sakarya University Journal of Science, 22(1), 24-38.

Kingma, D. P., and Ba, J. (2014). Adam: A method for stochastic optimization. arXiv preprint arXiv:1412.6980.

Kiperwasser, E., and Goldberg, Y. (2016). Simple and accurate dependency parsing using bidirectional LSTM feature representations. Transactions of the Association for Computational Linguistics, 4, 313327.

Köse, B., Atila, Ü., Güneşer, M. T., and Recebli, Z. (2016). An Approach to Estimate Hourly \& Daily Mean Wind Speed and Comparison with Artificial Neural Network. 10th International Clean Energy Symposium, 24-26 October, İstanbul, Turkey, 928-938.

KPMG Enerji (2019). Sektörel Baksş. https://assets.kpmg/content/dam/kpmg/tr/pdf/2019/03/sektorel-bakis-2019-enerji.pdf. (05.09.2020). 
Lam, J. C., Wan, K. K. W., and Yang, L. (2008). Solar radiation modeling using ANNs for different climates in China. Energy Conversion and Management, 49, 1-11.

LeCun, Y., Bengio, Y., and Hinton, G. (2015). Deep learning. Nature, 521(7553), 436-444.

Li, S., Wunsch, D. C., O'Hair, E. A., and Giesselmann, M. G. (2001). Using neural networks to estimate wind turbine power generation. IEEE Transactions on energy conversion, 16(3), 276-282.

Li, Z., Rahman, S. M., Vega, R., and Dong, B. (2016). A hierarchical approach using machine learning methods in solar photovoltaic energy production forecasting. Energies, 9(1), 55-67.

Mabel, M. C., and Fernandez, E. (2008). Analysis of wind power generation and prediction using ANN: A case study. Renewable energy, 33(5), 986-992.

Mellit, A., Sağlam, S., and Kalogirou, S. A. (2013). Artificial neural network-based model for estimating the produced power of a photovoltaic module. Renewable Energy, 60, 71-78.

MMO Makine Mühendisleri Odası (2014). Türkiye'nin Enerji Görünümü Oda Raporu. https://www.mmo.org.tr/sites/default/files/9aca139809cf620_ek_0.pdf (01.09.2020).

MMO Makine Mühendisleri Odası (2020). Türkiye'nin Enerji Görünümü 2020 Oda Raporu. https://www.mmo.org.tr/sites/default/files/TEG-2020-

00_Sunu\%C5\%9F_\%C4\%B0\%C3\%A7indekiler.pdf (01.09.2020).

Mohandes, M., Rehman, S., and Halawani, T. O. (1998). Estimation of global solar radiation using artificial neural networks. Renewable Energy, 14, 179-184.

Özden, S., and Öztürk, A. (2018). Yapay sinir ağları ve zaman serileri yöntemi ile bir endüstri alanının (ivedik OSB) elektrik enerjisi ihtiyaç tahmini. Bilişim Teknolojileri Dergisi, 11(3), 255-261.

Özsoy, M. F., and Aydogan, H. (2017). Türkiye'de Rüzgâr Enerjisi Kurulu Gücün Yapay Sinir Ağı ile Tahmini. 1st International Symposium on Multidisciplinary Studies and Innovative Technoloogies, 0204 November, Tokat, Turkey, 167-170.

Park, D. C., El-Sharkawi, M. A., Marks, R. J., Atlas, L. E., and Damborg, M. J. (1991). Electric load forecasting using an artificial neural network. IEEE transactions on Power Systems, 6(2), 442-449.

Reddy, K. S., and Ranjan, M. (2003). Solar resource estimation using artificial neural networks and comparison with other correlation models. Energy Conversion and Management, 44, 2519-2530.

Rehman, S., and Mohandes, M. (2008). Artificial neural network estimation of global solar radiation using air temperature and relative humidity. Energy Policy, 36(2), 571-576.

Ruder, S. (2016). An overview of gradient descent optimization algorithms. arXiv preprint arXiv:1609.04747.

Salamon, J., and Bello, J. P. (2017). Deep convolutional neural networks and data augmentation for environmental sound classification. IEEE Signal Processing Letters, 24(3), 279-283. 
Senkal, O., and Kaleli, T. (2009). Estimation of solar radiation over Turkey using artificial neural network and satellite data. Applied Energy, 86, 1222-1228.

Sözen, A. (2004). Use of artificial neural networks for mapping of solar potential in Turkey. Applied Energy, 77, 273-286.

Sözen, A., Arcaklioglu, E., Ozalp, M., and Caglar, N. (2005). Forecasting based on neural network approach of solar potential in Turkey. Renewable Energy, 30, 1075-1090.

Şahan, M., and Yüksel, O. (2016). Akdeniz bölgesine ait meteorolojik veriler kullanılarak yapay sinir ağları yardımıyla güneş enerjisinin tahmini. Süleyman Demirel Üniversitesi Fen Edebiyat Fakültesi Fen Dergisi, 11(1), 61-71.

Şenol, Ü. (2017). Rüzgar enerjisi ve rüzgar enerjisi potansiyelinin yapay sinir ağları yöntemiyle tahmini. Yozgat Bozok University Graduate School of Science, Master's Thesis, Yozgat.

Şenol, Ü., and Musayev, Z. (2017). Rüzgâr Enerjisinden Elektrik Üretiminin Yapay Sinir Ağları İle Tahmini. Bilge Uluslararası Fen ve Teknoloji Araştırmaları Dergisi, 1(1), 23-31.

Taşcıkaraoğlu, A., and Uzunoğlu, M. (2011). Dalgacık Dönüşümü ve Yapay Sinir Ağları ile Rüzgâr Hızı Tahmini. Elektrik-Elektronik ve Bilgisayar Sempozyumu, 03-07 October, Elazı̆̆, Turkey, 106-111.

TEİAŞ Türkiye Elektrik İletim A.Ş. (2019). Yük Tevzi Dairesi Başkanlığı - Kurulu Güç Raporu - Aralık 2019. https://www.teias.gov.tr/tr-TR/kurulu-guc-raporlari (26.09.2020).

TEİAŞ Türkiye Elektrik İletim A.Ş. (2020). Yük Tevzi Daire Başkanlığı Kurulu Güç Raporu-Temmuz 2020. https://www.teias.gov.tr/tr-TR/kurulu-guc-raporlari (26.09.2020).

Ticknor, J. L. (2013). A Bayesian regularized artificial neural network for stock market forecasting. Expert Systems with Applications, 40(14), 5501-5506.

Uğuz, S., Oral, O., and Çağlayan, N. (2019). PV Güç Santrallerinden Elde Edilecek Enerjinin Makine Öğrenmesi Metotları Kullanılarak Tahmin Edilmesi. International Journal of Engineering Research and Development, 11(3), 769-779.

Yildirim, Ö. (2018). A novel wavelet sequence based on deep bidirectional LSTM network model for ECG signal classification. Computers in biology and medicine, 96, 189-202.

Zhou, J., Wu, Y. Z., and Yan, G. (2005). Solar radiation estimation using artificial neural networks. Journal of Solar Energy, 26, 509-512.

Zhou, P., Qi, Z., Zheng, S., Xu, J., Bao, H., and Xu, B. (2016). Text classification improved by integrating bidirectional LSTM with two-dimensional max pooling. arXiv preprint arXiv:1611.06639, $1-11$. 